\title{
Glycation of low-density lipoproteins by methylglyoxal and glycolaldehyde gives rise to the in vitro formation of lipid-laden cells
}

Received: 8 June 2004 / Accepted: 11 September 2004 / Published online: 20 January 2005

(C) Springer-Verlag 2005

\begin{abstract}
Aims/hypothesis: Previous studies have implicated the glycoxidative modification of low-density lipoprotein (LDL) by glucose and aldehydes (apparently comprising both glycation and oxidation), as a causative factor in the elevated levels of atherosclerosis observed in diabetic patients. Such LDL modification can result in unregulated cellular accumulation of lipids. In previous studies we have characterized the formation of glycated, but nonoxidized, LDL by glucose and aldehydes; in this study we examine whether glycation of LDL, in the absence of oxidation, gives rise to lipid accumulation in arterial wall cell types. Methods: Glycated LDLs were incubated with macrophage, smooth muscle, or endothelial cells. Lipid loading was assessed by HPLC analysis of cholesterol and individual esters. Oxidation was assessed by cholesterol ester loss and 7-ketocholesterol formation. Cell viability was assessed by lactate dehydrogenase release and cell protein levels. Results: Glycation of LDL by glycolaldehyde and methylglyoxal, but not glucose (in either the presence or absence of copper ions), resulted in cholesterol and cholesterol ester accumulation in macrophage cells, but not smooth muscle or endothelial cells. The extent of lipid accumulation depends on the degree of glycation, with increasing aldehyde concentration or incubation time, giving rise to greater extents of particle modification and lipid accumulation. Modification of lysine residues appears to be a key determinant of cellular uptake.
\end{abstract}

None of the authors have any commercial interests with any companies that might constitute a conflict of interest with regard to the data reported in this manuscript.

B. E. Brown · M. J. Davies $(\bowtie)$

Free Radical Group, The Heart Research Institute,

145 Missenden Road, Camperdown,

Sydney, 2050, Australia

e-mail: m.davies@hri.org.au

Tel.: +61-2-95503560

Fax: $+61-2-95503302$

R. T. Dean

University of Canberra,

Bruce, 2601, Australia
Conclusions/interpretation: These results are consistent with LDL glycation, in the absence of oxidation, being sufficient for rapid lipid accumulation by macrophage cells. Aldehyde-mediated "carbonyl-stress" may therefore facilitate the formation of lipid-laden (foam) cells in the artery wall.

Keywords Aldehydes - Atherosclerosis - Carbonyl stress · Cholesterol esters - Foam cell glycation - Glycoxidation . Low-density lipoproteins · Oxidation · Protein modification

Abbreviations AcLDL: LDL modified by acetylation ApoB-100: apolipoprotein B-100 - BHT: butylated hydroxytoluene - GA-LDL: LDL modified by glycolaldehyde $\cdot \mathrm{gLDL} \pm \mathrm{Cu}^{2+}$ : LDL modified by glucose in the absence or presence of $\mathrm{Cu}^{2+} \cdot$ HBSS: Hanks' balanced salt solution - HS: human serum - LDH: lactate dehydrogenase - LPDS: lipoprotein-deficient serum · MGLDL: LDL modified by methylglyoxal - nLDL: native LDL - PPACK: $d$-phenylalanyl-l-arginine chloromethyl ketone $\cdot$ REM: relative electrophoretic mobility

\section{Introduction}

Diabetic complications are the major cause of mortality and morbidity in patients with diabetes. These complications include those of the microvascular and macrovascular systems, with the former inducing damage to the retina, nephrons, and peripheral nerves, whereas macrovascular disease is associated with accelerated atherosclerosis in the coronary, peripheral, and carotid arteries [1]. Patients with diabetes therefore suffer from an increased risk of developing coronary heart disease, cerebrovascular disease and peripheral vascular disease and associated myocardial infarction, stroke, limb amputations, and premature death [1]. This macrovascular disease is responsible for approximately $72 \%$ of deaths in patients with diabetes.

A number of features of diabetes mellitus have been proposed as contributing factors to atherosclerosis, includ- 
ing chronic hyperglycaemia and insulin resistance, dyslipidaemias, and abnormalities of haemostasis [2]. Macrovascular disease appears in most patients with type 2 diabetes, at or near the time of first diagnosis, consistent with a shared underlying pathogenesis [2]. A consistent and early feature of atherosclerotic lesions is the presence of lipid-laden (foam) cells, arising from macrophages or some types of smooth muscle cells, in the intima of the artery wall [3]. Low-density lipoproteins (LDL) are the proposed source of this lipid. The expression of native LDL receptors on arterial cells is tightly controlled and feedback regulated, consistent with the uncontrolled uptake of LDL and subsequent foam cell formation occurring via alternative receptors [4]; a number of these have been characterized, including CD36, scavenger receptors A and B1, and RAGE [5]. These receptors recognize abnormal LDLs, but not native LDLs, including those modified by oxidation, aggregation, chemical modification, and immune complex formation $[4,6]$.

Of particular relevance to diabetes-associated atherosclerosis is the role of glucose (or species derived from glucose) in inducing modifications to LDL [7, 8]. Previous studies have identified glycation and glycoxidation reactions as mechanisms by which such alteration can occur [7]. Glycation involves the covalent binding of the aldehyde groups of glucose (or low-molecular-mass compounds derived from glucose or other compounds) to reactive amine (e.g., Lys and Arg side chains and the $\mathrm{N}$ terminus), and possibly cysteine, groups on the apoB-100 protein $[9,10]$. The initial product of such reactions is an unstable Schiff base, which undergoes subsequent rearrangement to yield Amadori products.

Glycoxidation consists of two related processesoxidation of protein-bound sugars (e.g., those arising from glycation) and oxidation of free glucose and its products. Each of these mechanisms can generate free radicals that modify LDL, and hence potentially play a role in the enhanced uptake of lipids by cells in the artery wall of patients with diabetes [10-13].

The species formed by glycation and glycoxidation can undergo subsequent chemical reactions to give complex products termed advanced glycation end-products (AGE) $[7,10]$. These include $\mathrm{N}^{\varepsilon}$-(carboxymethyl)lysine, $\mathrm{N}^{\varepsilon}$-(carboxyethyl)lysine, and pentosidine, which are known to accumulate with age in tissue proteins, and at an increased rate in LDL and atherosclerotic lesions from patients with diabetes [12, 14-16]. Both $\mathrm{N}^{\varepsilon}$-(carboxymethyl)lysine and $\mathrm{N}^{\varepsilon}$-(carboxyethyl)lysine are formed on reaction of lysine residues with low-molecular-mass aldehydes (glyoxal/ glycolaldehyde and methylglyoxal, respectively) [17], providing evidence for a role for such aldehydes in diabetesinduced complications. The plasma concentrations of these aldehydes are elevated in patients with diabetes [18, 19], and the role of AGE products in diabetic complications has been studied extensively [20, 21].

The significance of glycation versus the two facets of glycoxidation in giving rise to LDL modification, and subsequent foam cell formation, either in vitro or in vivo are incompletely understood. Most previous studies have employed conditions where either all of these processes have occurred, or where the nature of the LDL modification has not been adequately quantified (e.g., [11, 22]). It is therefore unclear as to what types, and extents, of modification of LDL induced by glucose or aldehydes, influence the potential formation of foam cells.

In previous studies we have developed reaction conditions which result in the formation of glycated LDL in the absence of significant (glyc)oxidation [23]. In the current work we examine whether glycation of LDL particles by glucose, or the aldehydes methylglyoxal and glycolaldehyde, in the absence of oxidation, can give rise to model lipid-laden (foam) cells on incubation with macrophage, endothelial, and smooth muscle cell lines in vitro. Furthermore, we have investigated the effectiveness of glucose (in the absence or presence of copper ions) versus low-molecular-mass aldehydes, in inducing LDL glycation and model foam cell formation.

\section{Materials and methods}

Materials Reagents were obtained from the following sources. Sigma-Aldrich (Castle Hill, NSW, Australia): methylglyoxal, glycolaldehyde, fatty acid-free BSA, chloramphenicol, BHT, EDTA, aprotinin, soybean trypsin inhibitor, thrombin, Fat Red 7B, Coomassie brilliant blue, type 1A collagenase, HBSS, PenStrep (containing 100 units $/ \mathrm{ml}$ penicillin and $0.1 \mathrm{mg} / \mathrm{ml}$ streptomycin), and Dulbecco's phosphate-buffered saline; BDH (Merck, Kilsyth, VIC, Australia): glucose and PPACK; Bio-Rad (Regents Park, NSW, Australia): pre-cast 4-15\% SDS-PAGE Gels and Chelex-100 resin; ICN (Seven Hills, NSW, Australia): $\mathrm{CuSO}_{4}$; Amersham Biosciences (Castle Hill, NSW, Australia): PD10 columns; Helena Laboratories (Mt. Waverly, VIC, Australia): pre-cast 1\% agarose gels; JRH Biosciences (CSL, North Ryde, NSW, Australia): DMEM, M199, and RPMI 1640 media; Trace Scientific (Melbourne, VIC, Australia): glutamine, sodium pyruvate, and trypsin/EDTA 1:250; Gibco (Melbourne, VIC, Australia): fetal calf serum (FCS); Australian Red Cross Clarence St Blood Bank: HS (human serum); Axis-Shield (Oslo, Norway): Lymphoprep; Starrate (Bethungra, NSW, Australia): endothelial cell growth promoter. Gases $(\geq 99.9 \%)$ were from Linde (Yennora, NSW, Australia). All other chemicals were of analytical or HPLC grade.

Solutions were prepared with nanopure water (Milli Q system; Millipore-Waters, Lane Cove, NSW, Australia) treated with washed Chelex-100 resin to remove transition metal ions, with the exception of tissue culture reagents where Baxter (Old Toongabbie, NSW, Australia) sterile, endotoxin-free, water, PBS, or HBSS were used.

LDL isolation Plasma was isolated from blood obtained from healthy volunteers with informed consent. Blood was collected in $0.01 \mathrm{mmol} / 1$ EDTA, $1 \mu \mathrm{l}$ aprotinin, $0.04 \mu \mathrm{mol} / 1$ PPACK, and $20 \mu \mathrm{g} / \mathrm{ml}$ soybean trypsin inhibitor per millilitre of whole blood [24]. LDL (density 1.019-1.050) was isolated by sequential density gradient ultracentrifuga- 
tion (L-80 Optima; Beckman, Palo Alto, CA, USA) in degassed $\mathrm{KBr}$ solutions [25], using a vertical rotor (VTi50; Beckman) at $10^{\circ} \mathrm{C}$ for $2.5 \mathrm{~h}(206,000 \mathrm{~g}$ average $)$. The LDL was washed by ultracentrifugation, density 1.064 , in an angle rotor (Ti70; Beckman) for $20 \mathrm{~h}$ (184,000 $\mathrm{g}$ average) at $10^{\circ} \mathrm{C}$ and then dialysed overnight at $4^{\circ} \mathrm{C}$, with four changes of 11 degassed PBS containing $1 \mathrm{mg} / \mathrm{ml}$ EDTA and $0.1 \mathrm{mg} / \mathrm{ml}$ chloramphenicol. LDL was stored sterile $\left(0.45 \mu \mathrm{m}\right.$ filtered) in the dark at $4^{\circ} \mathrm{C}$ and used within 3 weeks of isolation. Before the LDL was used, EDTA was removed by elution of the LDL through two successive PD10 columns as per the manufacturer's instructions using chelexed PBS.

Lipoprotein-deficient serum Lipoprotein-deficient serum (LPDS) was prepared from the LDL-deficient infranatant of healthy male donors after density ultracentrifugation as previously [26]. The LDL was adjusted to density 1.25 with $\mathrm{KBr}$ and ultracentrifuged (Ti70; Beckman) at $10^{\circ} \mathrm{C}$ for $20 \mathrm{~h}(184,000 \mathrm{~g})$ to remove other lipoproteins.

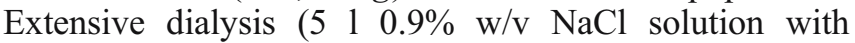
$0.1 \mathrm{mg} / \mathrm{ml}$ chloramphenicol $\times 5$ days) was performed to remove $\mathrm{KBr}$ before clotting of the LPDS with $1 \mathrm{ml} 1 \mathrm{~mol} / 1$ $\mathrm{CaCl}_{2}$ and $55 \mathrm{U}$ thrombin per $100 \mathrm{ml}$ LPDS at $37^{\circ} \mathrm{C}$. LPDS was then filtered to remove clots, heat inactivated, sterile filtered $(0.22 \mu \mathrm{m})$, and stored frozen, at approximately $20 \mathrm{mg} / \mathrm{ml}$ protein concentration, at $-20^{\circ} \mathrm{C}$.

LDL modifications Acetylation of LDL was carried out by a modification of previous methods [27], with $6 \mu \mathrm{l}$ acetic anhydride added per milligram LDL protein [28]. Modification of LDL by glycolaldehyde, methylglyoxal, or glucose was carried out as described previously [23]. Briefly, sterile LDL ( $1 \mathrm{mg} / \mathrm{ml}$ protein) was incubated with 1-100 mmol/l glycolaldehyde, methylglyoxal, or glucose $\left( \pm 1 \mu \mathrm{mol} / 1 \mathrm{CuSO}_{4}\right)$ in chelexed PBS at $37^{\circ} \mathrm{C}$ under $5 \%$ (v/v) $\mathrm{CO}_{2}$. Incubation controls contained $50 \mu \mathrm{mol} / 1$ EDTA in place of glucose or aldehyde. Excess reagents were subsequently removed by elution of the LDL through two successive PD10 columns as per the manufacturer's instructions using chelexed PBS.

Agarose gel electrophoresis LDL $(10-15 \mu \mathrm{l})$ was loaded onto $1 \%$ agarose gels and run on a Ciba-Corning (Palo Alto, CA, USA) system (45 min, $90 \mathrm{~V}, \mathrm{pH} 8.6$ barbitone buffer). Gels were fixed with $100 \%$ methanol $(30 \mathrm{~s})$, stained with Fat Red 7B, and destained with $70 \%$ methanol. The relative electrophoretic mobility (REM) of the LDL particles was determined relative to native LDL (REM set to 1).

$S D S-P A G E$ Equal volumes were mixed of $1 \mathrm{mg} / \mathrm{ml} \mathrm{LDL}$ and sample loading buffer containing 10\% (w/v) SDS, $10 \%(\mathrm{v} / \mathrm{v})$ glycerol, $2.5 \%(\mathrm{v} / \mathrm{v})$ saturated bromophenol blue, and 5\% (v/v) 2-mercaptoethanol in $300 \mathrm{mmol} / 1$ Tris$\mathrm{HCl}\left(\mathrm{pH} \mathrm{6.8)}\right.$. Samples were heated at $100^{\circ} \mathrm{C}$ for $5 \mathrm{~min}$, then $25 \mu \mathrm{l}$ was loaded per well on $4-15 \%$ precast SDSpolyacrylamide gels and run $(150 \mathrm{~V}, 50 \mathrm{~min}$, SDS trisglycine buffer) using a BioRad (Regents Park, NSW,
Australia) system. Bands were visualized with Coomassie brilliant blue $[29,30]$. Gels were digitized using a Bio-Rad (Hercules, CA, USA) Gel Doc 1000 system.

Cell culture Media contained $4 \mathrm{mmol} / \mathrm{l}$ glutamine and 1\% $(\mathrm{v} / \mathrm{v})$ PenStrep and $10 \%(\mathrm{v} / \mathrm{v})$ heat-inactivated FCS or HS, unless specified otherwise. Cells were cultured in humidified incubators $\left(5 \% \mathrm{CO}_{2}, 37^{\circ} \mathrm{C}\right)$ in $175-\mathrm{cm}^{2}$ flasks or 12 well (22-mm) plates (Becton Dickinson, Franklin Lakes, NJ, USA).

J774A.1 mouse macrophages (TIB-67; ATCC, Manassas, VA, USA) were grown in DMEM media with $10 \%$ FCS and supplements as described above. For experiments, confluent J774.A1 cells were harvested and replated in 12well plates at $0.5 \times 10^{6}$ cells $/ \mathrm{ml}$ and incubated overnight before use.

Human umbilical vein endothelial cells (HUVECs) were harvested from freshly obtained cords using type 1A collagenase $\left(15 \mathrm{~min}, 37^{\circ} \mathrm{C}\right)$ [31], and established as primary cell cultures in M199 media containing 20\% HS, glutamine, and PenStrep (as above), and $0.5 \%(\mathrm{v} / \mathrm{v})$ endothelial cell growth promoter. Cells were used up to passage 4 . Tissue culture flasks and plates were pretreated with Gelofusine in PBS (1:250) before replating. Confluent cells were harvested using trypsin/EDTA (1:250), diluted to $0.2 \times 10^{6}$ cells $/ \mathrm{ml}$, and replated in $12-w e l l$ plates overnight before use.

A7r5 rat aortic smooth muscle cells (CRL-1444; ATCC, Manassas, VA, USA) were cultured in RPMI 1640 media with $10 \% \mathrm{FCS}$, supplements as described above, $1 \mathrm{mmol} / 1$ sodium pyruvate, and $3.5 \mathrm{~g} / \mathrm{l}$ glucose. Confluent cells were trypsinized and replated as described above for endothelial cells. For serum-deprivation experiments, cells were plated down at $0.1 \times 10^{6}$ cells $/ \mathrm{ml}$ in 12 -well plates in $10 \%$ FCS overnight, and then incubated in $0.2 \%$ FCS for $48 \mathrm{~h}$; such cells were subconfluent when used.

Cell loading with modified $L D L$ Cells were exposed to 0-200 $\mu \mathrm{g} / \mathrm{ml}$ modified LDL for 1-4 days in media containing 10\% LPDS. Acetylated LDL (AcLDL) was employed as a positive control. After exposure, cells were equilibrated using media containing $1 \mathrm{mg} / \mathrm{ml} \mathrm{BSA}$ instead of serum for $2-24 \mathrm{~h}$, depending on cell type. Cells were then lysed in water, and the lysate extracted for cholesterol and cholesteryl ester analysis. Cell viability was determined by lactate dehydrogenase (LDH) release [32].

Cholesterol and cholesteryl ester analysis Cell lysate $(800 \mu \mathrm{l})$ was added to $10 \mu \mathrm{l} 200 \mathrm{mmol} / \mathrm{l}$ EDTA and $10 \mu \mathrm{l}$ $0.2 \mathrm{mmol} / \mathrm{l} \mathrm{BHT}$, and extracted with $200 \mu \mathrm{l}$ water (or for LDL samples: $20 \mu \mathrm{LDL}$ and $980 \mu \mathrm{l} \mathrm{PBS}$ ), $2.5 \mathrm{ml}$ methanol, and $5 \mathrm{ml}$ hexane. Samples were mixed thoroughly and stored at $-20^{\circ} \mathrm{C}$ until processed. Samples were centrifuged $(2,060 \mathrm{~g}, 5 \mathrm{~min})$ and $4 \mathrm{ml}$ of the hexane layer removed and dried down under vacuum. Samples were redissolved in HPLC mobile phase $(200 \mu \mathrm{l})$ and transferred to HPLC vials. Cholesterol and cholesteryl esters were quantified at $205 \mathrm{~nm}$ by reverse-phase HPLC [33] 
using a Supelco (Castle Hill, NSW, Australia) ODS LC-18 column $(25 \times 0.46 \mathrm{~cm}, 5 \mu \mathrm{m}$ particle size $)$ and a $2-\mathrm{cm}$ Pelliguard column at $25^{\circ} \mathrm{C}$, on a Shimadzu HPLC system (SPD-M10AVP diode array UV detector, SIL-10ADVP auto injector and cooler, LC-10AT pump, SCL-10AVP system controller, PC running Class-VP software; Kyoto, Japan). Cholesterol and cholesteryl esters were separated isocratically at $1 \mathrm{ml} / \mathrm{min}$ with $70 \%$ isopropanol $/ 30 \%$ acetonitrile $(\mathrm{v} / \mathrm{v})$. Solvents were filtered and degassed prior to use and flushed with helium. 7-Ketocholesterol was analysed using the same HPLC system, but with detection at $234 \mathrm{~nm}$ and a mobile phase consisting of 54\% isopropanol, $44 \%$ acetonitrile, and $2 \% \mathrm{H}_{2} \mathrm{O}(\mathrm{v} / \mathrm{v} / \mathrm{v})$ [33]. Cholesterol, cholesteryl docosahexaenoate, cholesteryl arachidonate, cholesteryl linoleate, cholesteryl palmitate, cholesteryl oleate, cholesteryl sterate and 7-ketocholesterol levels were quantified by use of standards (Sigma, Castle Hill, NSW, Australia) and expressed as $\mathrm{nmol} / \mathrm{mg}$ cell protein or $\mathrm{nmol} /$ mg apoB protein.

Protein assay LDL and cell lysate protein concentrations were quantified using the bicinchoninic acid (BCA) assay (Pierce, Rockford, IL, USA), using a 60-min incubation at $60^{\circ} \mathrm{C}$, and BSA for standards.

Data analysis Data are expressed as mean \pm standard error of the mean (SEM) from three or more separate experiments, unless stated otherwise. Statistics were by one-way or two-way analysis of variance (ANOVA) with Tukey's post hoc analysis; $P<0.05$ was taken as statistically significant.

\section{Results}

LDL characterization Incubations of LDL were carried out as described previously [23] using conditions which give minimal oxidation of protein, lipids, cholesterol, or antioxidants, but extensive glycation of the apoB protein. Additional experiments to characterize changes in particle charge (as assessed by relative electrophoretic mobility [REM]) and aggregation (by SDS-PAGE) were carried out in the current study. The REM assay measures the overall total charge on the LDL particle; as a result of the loss of positive charge arising from the modification of Lys and Arg residues, an increase in overall negative charge is detected with increasing extents of particle alteration. Acetylated LDL (AcLDL) was used in both assays as a positive control.

Incubation of $1 \mathrm{mg} / \mathrm{ml} \mathrm{LDL}$ with 10 or $100 \mathrm{mmol} / 1$ methylglyoxal or glycolaldehyde led to significant concentration- and time-dependent changes in the REM of the LDL particles (Fig. 1). Statistically significant increases were detected by $24 \mathrm{~h}$, with values for the aldehyde-treated LDL threefold to fivefold greater than those for incubation controls (LDL with $50 \mu \mathrm{mol} / \mathrm{l}$ EDTA; Fig. 1a, b). No significant difference was observed between 10 and $100 \mathrm{mmol} / \mathrm{l}$ methylglyoxal at $24 \mathrm{~h}$ (Fig. 1b), whereas $100 \mathrm{mmol} / 1$ glycolaldehyde generated signifi-
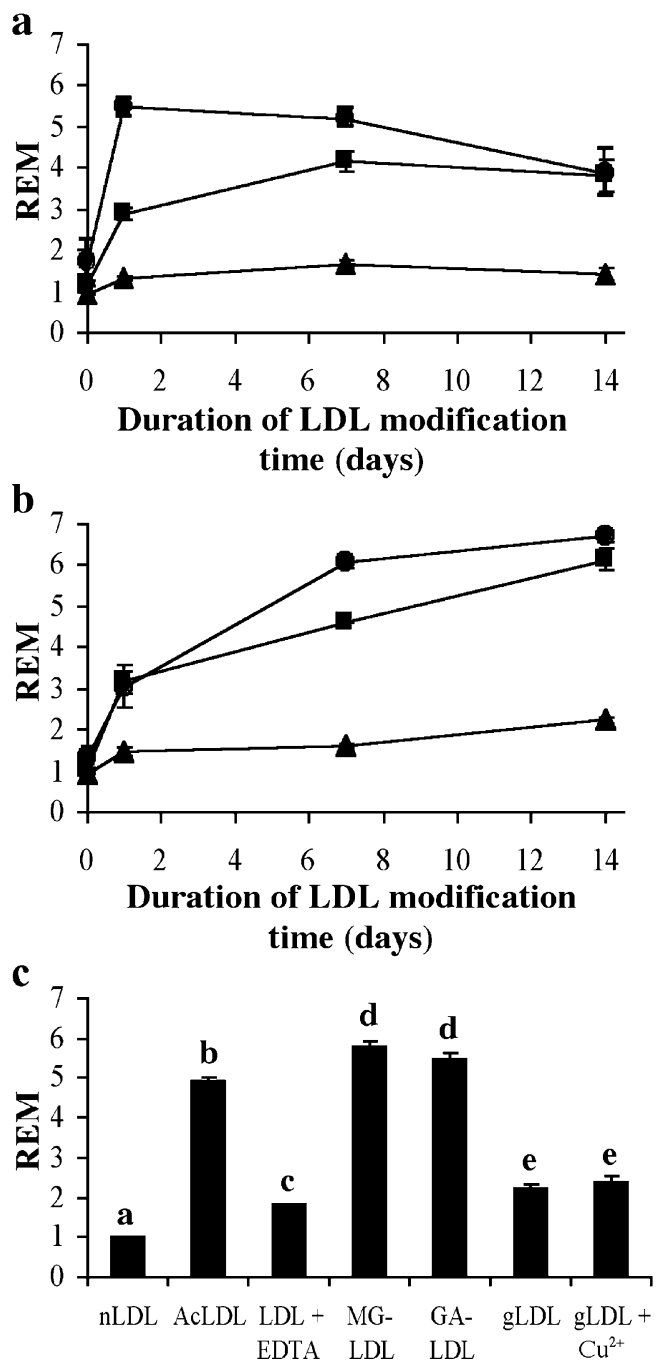

Fig. 1 Relative electrophoretic mobility (REM, a measure of particle charge) of LDL modified by 0 (triangles), 10 (squares), or $100 \mathrm{mmol} / 1$ (circles) glycolaldehyde (a) or methylglyoxal (b) with increasing incubation time at $37^{\circ} \mathrm{C}$. All REM values for the treated samples are statistically elevated compared to the $0 \mathrm{mmol} / 1$ controls at each time point. c Comparison of the REM values for normal LDL (nLDL, nonincubated), LDL modified by acetylation (AcLDL), LDL incubated with $50 \mu \mathrm{mol} / 1$ EDTA for 7 days (LDL+EDTA, incubation control), LDL modified by $100 \mathrm{mmol} / 1$ methylglyoxal over 7 days (MG-LDL), LDL modified by $100 \mathrm{mmol} / 1$ glycolaldehyde over 7 days (GA-LDL), or LDL modified with $100 \mathrm{mmol} / 1$ glucose $\left( \pm 1 \mu \mathrm{mol} / 1 \mathrm{Cu}^{2+}\right)$ for 7 days. Columns with different letters above them are significantly different by one-way ANOVA $(P<0.05)$.

cantly greater changes than $10 \mathrm{mmol} / \mathrm{l}$ glycolaldehyde (Fig. 1a). The rate of increase in REM values decreased at longer time points with these reaching a plateau value after 1-2 weeks for glycolaldehyde. Those for methylglyoxal continued to increase over the entire period studied (Fig. 1a, b). A significant increase in the REM value for the incubation control was detected by 7 days (Fig. 1c). Small, but statistically significant, changes were detected for glucose with or without $\mathrm{Cu}^{2+}\left(\mathrm{gLDL} \pm \mathrm{Cu}^{2+}\right.$; REM ca. 2.3 in each case versus 1.8 for LDL+EDTA incubation controls; Fig. 1c). No statistical difference was observed between the samples with or without $\mathrm{Cu}^{2+}$ (Fig. 1c). The 


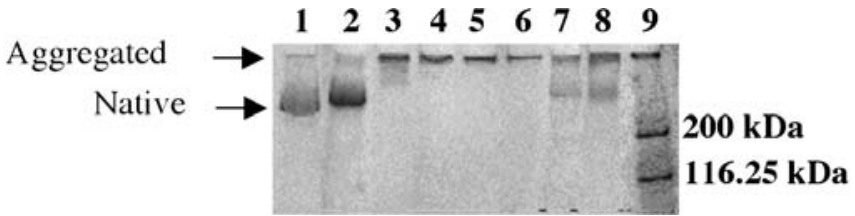

Fig. 2 SDS-PAGE of native LDL (lane 1), or LDL modified by 7 days of incubation with $50 \mu \mathrm{mol} / \mathrm{l}$ EDTA (lane 2), 10 and $100 \mathrm{mmol} / \mathrm{l}$ methylglyoxal (lanes 3-4), 10 and $100 \mathrm{mmol} / 1$ glycolaldehyde (lanes $5-6$ ), $100 \mathrm{mmol} / 1$ glucose (lane 7) or $100 \mathrm{mmol} / 1$ glucose plus $1 \mu \mathrm{mol} / 1 \mathrm{Cu}^{2+}$ (lane 8). Lane 9: molecular weight markers. Representative gel of two, with samples run in triplicate.

changes in REM for methylglyoxal-modified LDL (MGLDL) and glycolaldehyde-modified LDL (GA-LDL) after 7 days were not significantly different from one another, but were significantly higher than for acetylated LDL (AcLDL) and incubation controls (Fig. 1c).

Significant aggregation was observed on SDS-PAGE reducing gels for LDL modified by methylglyoxal, glycolaldehyde, and to a lesser extent glucose (Fig. 2). This effect was concentration- and aldehyde-dependent and increased with longer incubation times for all conditions (data not shown). More extensive aggregation was ob- served for LDL modified with $10 \mathrm{mmol} / 1$ glycolaldehyde than methylglyoxal (Fig. 2, lane 3 versus 5). With higher aldehyde concentrations, only low amounts of the LDL entered the gel from the loading wells (cf. Fig. 2, lane 6) consistent with extensive aggregation. For LDL incubated with $100 \mathrm{mmol} / 1$ glucose, with or without $1 \mu \mathrm{mol} / 1 \mathrm{Cu}^{2+}$, aggregation was less marked (Fig. 2, lanes 7 and 8) than with either aldehyde.

Under the conditions employed, the concentrations of cholesterol, cholesteryl docosahexaenoate, cholesteryl arachidonate, cholesteryl linoleate, cholesteryl oleate, cholesteryl palmitate and cholesteryl stearate, and 7-ketocholesterol (a lipid oxidation product) in the LDL particles did not alter significantly on treatment with methylglyoxal, glycolaldehyde, or glucose (with or without $1 \mu \mathrm{mol} / 1$ $\mathrm{Cu}^{2+}$ ) when compared to native LDL, or incubation controls (LDL+EDTA) (data not shown). 7-Ketocholesterol accounted for $<0.1 \%$ of the total sterol in all cases (data not shown), and was $<1 \mathrm{nmol} / \mathrm{mg}$ apoB in controls.

This data is consistent with rapid and extensive glycation, but minimal oxidation of the lipids in these LDL particles. The effect of incubation of arterial wall cell types with these well-characterized glycated, but essentially
Fig. 3 Free cholesterol $(\mathbf{a}, \mathbf{d})$, total cholesteryl esters $(\mathbf{b}, \mathbf{e})$ and percentage cholesteryl esters of total cholesterol $(\mathbf{c}, \mathbf{f})$ present in J774A.1 cells, after exposure to $200 \mu \mathrm{g} / \mathrm{ml}$ of LDL for $24 \mathrm{~h}$ that had been previously modified for the stated period by 0 (triangles), 1 (diamonds), 10 (squares), or 100 (circles) $\mathrm{mmol} / \mathrm{l}$ methylglyoxal $(\mathbf{a}-\mathbf{c})$ or glycolaldehyde $(\mathbf{d}-\mathbf{f})$. Total cholesterol values are the sum of the values of free cholesterol plus total cholesteryl esters.

* Indicates statistically elevated values $(P<0.05)$ compared to the $0 \mathrm{mmol} / \mathrm{l}$ controls at each time point.
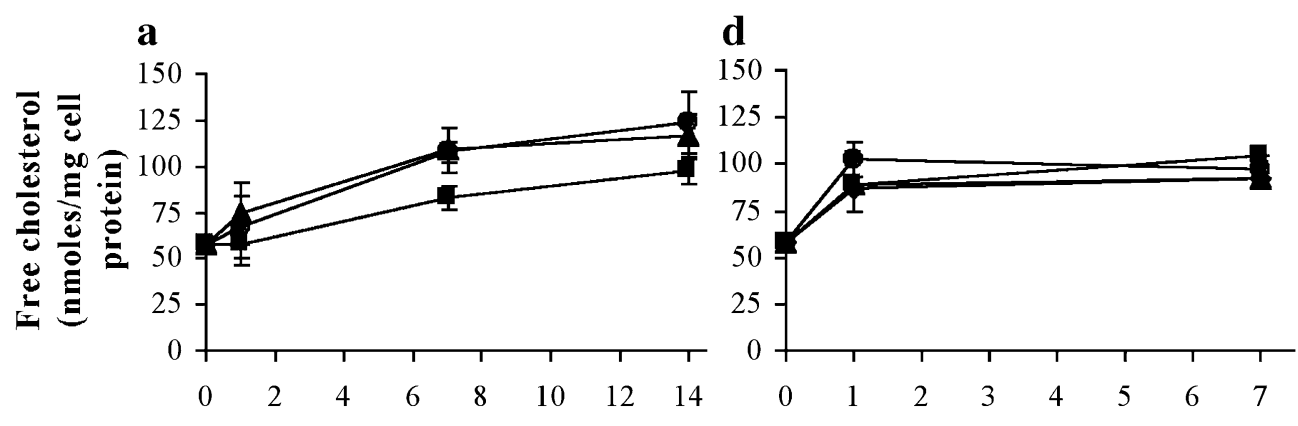

b

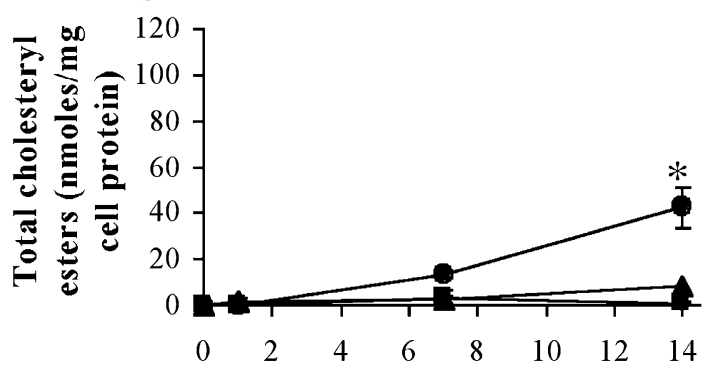

e
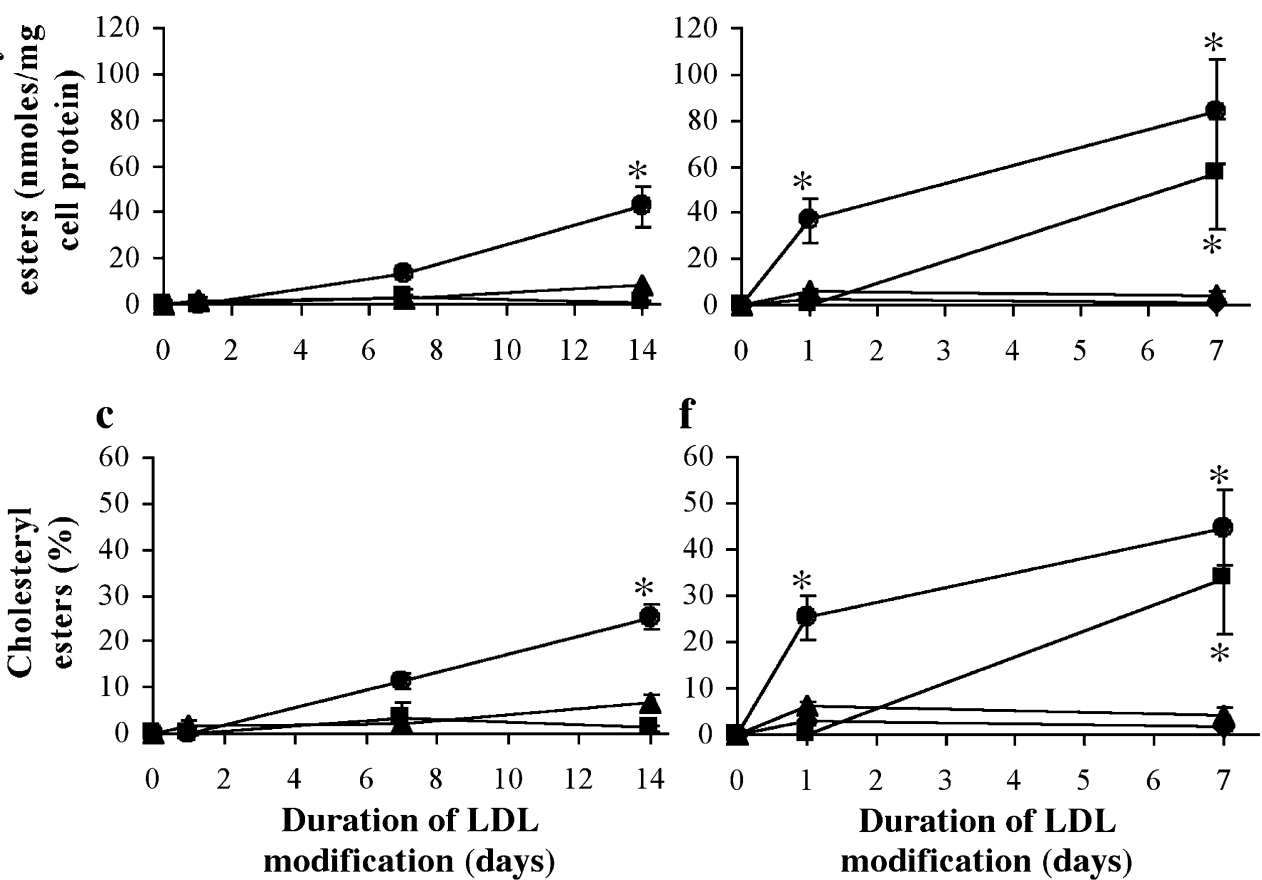

f

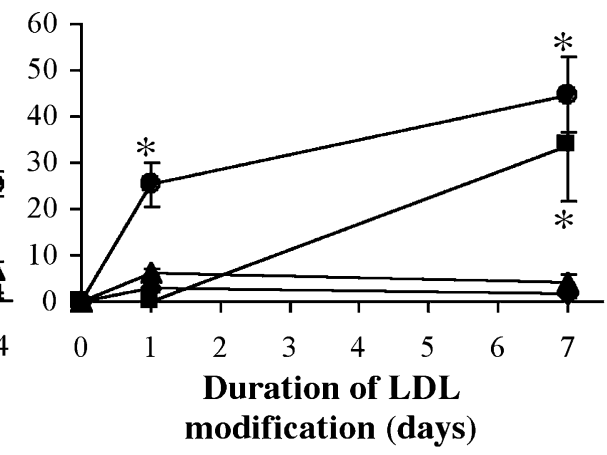


unoxidized, LDL particles was subsequently examined by assessing cell viability and cellular lipid accumulation.

Effect of glycated LDL particles on cell viability The effect of $0-200 \mu \mathrm{g} / \mathrm{ml}$ glycated or control LDL on the viability (assessed by LDH release and cell protein levels) of murine macrophages (J774A.1 cell line), A7r5 rat smooth muscle cells, and human umbilical vein endothelial cells (HUVECs) was assessed after incubation for $24 \mathrm{~h}$ (J774A.1 and A7r5 cells), or 48 h (HUVECs). In all cases, neither LDL modification nor the concentration of LDL employed had any significant effect on either parameter of cell viability (two-way ANOVA, $P>0.05$ ).

Lipid accumulation in macrophage cells Incubation of J774A. 1 murine macrophages for $24 \mathrm{~h}$ with $50-200 \mu \mathrm{g} / \mathrm{ml}$ of LDL which had been modified with $100 \mathrm{mmol} / 1$ glucose in the absence or presence of $\mathrm{Cu}^{2+}$ for up to 14 days, did not result in significantly increased cellular levels of total cholesterol or cholesterol esters, when compared to incubation controls (cells exposed to LDL which had been incubated under similar conditions with EDTA; data not shown). Experiments using 50-200 $\mu \mathrm{g} / \mathrm{ml}$ LDL modified by $10 \mathrm{mmol} / 1$ methylglyoxal for $24 \mathrm{~h}, 7$ or 14 days, or $100 \mathrm{mmol} / \mathrm{l}$ methylglyoxal for up to 7 days, also did not result in significant cholesterol or cholesteryl ester accumulation when compared to incubation controls (Fig. 3a-c). In contrast, LDL modified with $100 \mathrm{mmol} / 1$ methylglyoxal for 14 days did give rise to significant lipid accumulation (Fig. 3a-c). LDL $(50-200 \mu \mathrm{g} / \mathrm{ml})$ treated with $1 \mathrm{mmol} / \mathrm{l}$ glycolaldehyde, for any of the time periods examined, did not give rise to significant lipid accumulation (Fig. 3d-f), whereas LDL modified for 7 days (but not $24 \mathrm{~h})$ with $10 \mathrm{mmol} / 1$ glycolaldehyde gave a significant increase in cellular lipid levels (Fig. 3d-f). LDL modified by $100 \mathrm{mmol} / \mathrm{l}$ glycolaldehyde for $24 \mathrm{~h}$ or longer, also resulted in significant cellular accumulation of lipids (Fig. 3d-f).

Lipid accumulation in smooth muscle and endothelial cells Free cholesterol and cholesterol ester levels in A7r5 cells and HUVECs were not significantly affected by exposure (24 h for A7r5, $48 \mathrm{~h}$ for HUVECs) to $0-200 \mu \mathrm{g} / \mathrm{ml} \mathrm{LDL}$, preincubated with $0-100 \mathrm{mmol} / \mathrm{l}$ methylglyoxal or glycolaldehyde for 7 days, or $100 \mathrm{mmol} / \mathrm{l}$ glucose, in the absence or presence of $1 \mu \mathrm{mol} / 1 \mathrm{Cu}^{2+}$, for 14 days, when compared to cells incubated with control LDL as determined by twoway ANOVA (analysis of LDL concentration and modification; data not shown). Serum deprivation of A7r5 cells for $48 \mathrm{~h}$, before exposure to the modified LDL for $24 \mathrm{~h}$, also did not significantly affect cell viability, protein, free cholesterol, or total cholesterol ester levels.

\section{Discussion}

Although there is strong evidence for a role for glycation and glycoxidation in the pathogenesis of diabetes-associated macrovascular disease $[1,10]$, the processes re- sponsible for the formation of lipid-laden (foam) cells in the artery wall of patients with diabetes have not been fully resolved. Evidence had been presented for elevated levels of both glycoxidation (i.e., radical) and glycation (covalent addition) products on proteins, including the apolipoprotein B-100 protein of LDL, from patients with diabetes $[12,34]$. While it is established that oxidation of LDL can result in recognition by macrophage cell scavenger receptors [4], and that glycoxidized LDL can give rise to enhanced lipid uptake (see e.g., [11, 35]), the role of glycation is less clear-cut. Agents that modify lysine side chains (e.g., by acetylation, succinylation, or reaction with malondialdehyde $[6,36])$, can generate LDL particles that are recognized by macrophage scavenger receptors, with modification of $>16 \%$ of the lysine residues required [37]. Similar data have not been obtained for glycation reactions, although use of AGE-specific antibodies (which may recognize both glycation and glycoxidation products) have identified epitopes near the LDL receptor binding site as key sites [38, 39].

We have previously determined conditions that give rise to LDL glycation in the absence of significant oxidation of protein, lipid, cholesterol, or antioxidant components [23]. Glycation of the apoB protein of LDL by methylglyoxal and glycolaldehyde has also been shown to be more rapid than with glucose [23], in line with previous studies (e.g., [40]). The current study has examined whether these glycated, but nonoxidized, LDL particles can give rise to lipid loading in murine macrophage-like (J774A.1) cells, smooth muscle (A7r5) cells, and endothelial cells (HUVECs).

The incubation conditions employed in the current study gave extensive LDL glycation in the absence of significant oxidation. Time- and concentration-dependent changes in both the charge and degree of LDL aggregation were induced by methylglyoxal and glycolaldehyde, consistent with the loss of lysine, arginine, and tryptophan side chains detected previously [23]. Slower, and less dramatic, changes in charge and aggregation were detected with $100 \mathrm{mmol} / 1$ glucose. The presence of $\mathrm{Cu}^{2+} \mathrm{did}$ not influence these glucose reactions, though evidence has been presented for an accelerated oxidation of glycated and normal LDL by high concentrations of copper and iron at longer incubation times [23, 41, 42]. The rapid modification of LDL by methylglyoxal and glycolaldehyde (with the latter more efficient), but not glucose, is consistent with previous data for LDL $[23,43]$ and other proteins (e.g., [44-46]).

None of these modified LDL particles affected cell viability or protein levels. Similarly, these glycated particles, irrespective of the modifying agent or extent of modification, did not give rise to enhanced total cholesterol, total cholesterol ester, or percentage cholesterol ester levels when incubated with HUVECs or A7r5 smooth muscle cells. Serum deprivation of the A7r5 cells, to mimic a purported in vivo state $[47,48]$, also did not affect cellular viability, protein, free cholesterol, and total cholesterol ester levels. 
In contrast, significant lipid accumulation was detected, in some cases, with the macrophage cell line. The extent and rate of loading was dependent on the nature and concentration of the modifying agent, and the modification time. LDL modified by glucose, with or without $\mathrm{Cu}^{2+}$, did not give significant cholesterol or cholesterol ester accumulation, irrespective of the quantity of modified LDL to which the cells were exposed, or the incubation time of the LDL with the glucose. Similar behaviour was observed with LDL modified by low concentrations of methylglyoxal for any time period, or high concentrations of this agent for short periods. LDL modified by $100 \mathrm{mmol} / 1$ methylglyoxal for 14 days, gave rise to cholesterol ester accumulation when expressed either as nanomoles per milligram cell protein, or as a percentage of the total cholesterol present as esters. In the latter case, values of up to $25 \%$ were obtained. These positive data are in contrast to a previous study where methylglyoxal-modified LDL was found to cause significantly less cholesterol ester synthesis than native, oxidized, or acetylated LDL [43]. This may be due to the lower concentrations and shorter modification times used $(<10 \mathrm{mmol} / \mathrm{l}$ for $72 \mathrm{~h})$.

Significant cholesterol and cholesterol ester accumulation was detected with glycolaldehyde-modified LDL at early time points $(24 \mathrm{~h}$ modification, $100 \mathrm{mmol} / \mathrm{l}$ aldehyde) and at lower concentrations (e.g., $10 \mathrm{mmol} / \mathrm{l}$ glycolaldehyde for $>7$ days). With this aldehyde, cholesterol ester levels, when expressed as a percentage of total cholesterol, reached ca. $45 \%$ using $100 \mathrm{mmol} / 1$, and $34 \%$ for $10 \mathrm{mmol} / \mathrm{l}$. These values are similar to those detected in human atherosclerotic lesions [49].

Comparison of these data with the REM and SDS-PAGE studies, and those for amino acid modification determined previously [23], allows information to be determined as to the nature and level of LDL modification required for efficient lipid accumulation in these cells. Both REM and SDS-PAGE appear to be unreliable predictors, when used in isolation, of the ability of the modified LDL to give rise to loading. Thus the REM values for LDL incubated with 10 or $100 \mathrm{mmol} / \mathrm{l}$ methylglyoxal are greater than those for the 10 and $100 \mathrm{mmol} / \mathrm{l}$ glycolaldehyde-treated LDL after 7 days, yet the methylglyoxal-treated LDL did not give rise to significant loading whereas the glycolaldehyde-treated samples did. With each preparation, significant LDL aggregation was detected, yet only the glycolaldehydetreated samples gave rise to cholesterol and cholesterol ester accumulation. The extent of modification of some of the individual LDL amino acids (see [23]) appears to correlate more closely with lipid loading. Modification of tryptophan does not appear to correlate with loading, as significant loss of this residue is seen at short incubation times and with low methylglyoxal concentrations (e.g., $10 \mathrm{mmol} / \mathrm{l}$ ) that do not result in cholesterol ester accumulation. Arginine modification also does not appear to correlate with lipid loading. Thus incubation of LDL with $100 \mathrm{mmol} /$ 1 glucose results in the loss of $67 \%$ of these residues after 14 days - conditions where no cellular accumulation of lipid is seen-whereas LDL treated with $10 \mathrm{mmol} / 1$ glycolalde- hyde after $24 \mathrm{~h}$ or 7 days loses only ca. $20 \%$ of its arginine, yet extensive lipid accumulation is detected.

The extent of modification of lysine residues appears to be a key factor. These residues are lost to a greater extent, and more rapidly, with glycolaldehyde than methylglyoxal at all concentrations, and no loss was detected with $100 \mathrm{mmol} / \mathrm{l}$ glucose, even after 14 days in the presence of $\mathrm{Cu}^{2+}$. This incubation time is much longer than the residence time of normal LDL particles in plasma (ca. 2 days [50]), suggesting that the extent of modification induced by glucose in vivo is likely to be modest, though it should be noted that the residence time (and hence exposure time) of LDL in the intima of the artery wall may be longer (e.g. [51]). The residence time of LDL in plasma and/or intima may also play a key role in determining the relevance of glycation versus (glyc)oxidation reactions in vivo, in addition to other factors (e.g., metal ion levels which might catalyse these reactions).

This conclusion that lysine residues may be a key determinant of the recognition of modified LDL particles by the scavenger receptors of macrophage cells, and hence cellular accumulation, is in accord with studies using human monocyte-derived macrophages, where other regents (acetic anhydride, succinic anhydride, malondialdehyde) were used to induce lysine modification [36,37]. These previous studies concluded that $>16 \%$ modification of the lysine residues was required for scavenger receptor recognition $[36,37]$, whereas a much higher level appears to be required for the aldehydes studied here, as ca. $40 \%$ of the lysine residues were modified by $100 \mathrm{mmol} / \mathrm{l}$ methylglyoxal after $24 \mathrm{~h}$, yet cellular uptake was only detected when ca. $80 \%$ were lost after 14 days. This may indicate that it is the products of these reactions, rather then loss of the parent amino acid per se, which is the key determinant.

The extent of lysine modification achieved in this study is greater than that detected on LDL isolated from control or diabetic plasma, where levels of $2-5 \%$ have been reported [52]. The products of this modification are not fully elucidated. It has been reported that modified LDL isolated from diabetic plasma can stimulate cholesteryl ester synthesis in human monocyte-derived macrophages [53] - consistent with the current results. The extent of modification of lysine residues on LDL isolated from human atherosclerotic lesions has not been reported, so it is not possible to judge the extent, or type, of modification of LDL to which macrophage cells might be exposed in the intima of the artery wall.

Overall, these studies have demonstrated that LDL glycation, in the absence of significant oxidation, is sufficient to induce lipid loading in a murine macrophage cell line. Significant accumulation only occurs with LDL modified by aldehydes, and not glucose, and requires extensive modification of the lysine residues of the apoB-100 protein; the extent of lipid loading achieved is similar to that detected in atherosclerotic lesions. This process is specific to macrophages, and does not occur with the smooth muscle cell line or primary endothelial cells, and is consistent with the presence of receptors for glycated LDL only on macrophage cells. The uptake of aldehyde-modified LDL 
by macrophages within lesions may play a role in the enhanced atherosclerosis observed in patients with diabetes, as the concentrations of these aldehydes are known to be elevated in such patients $[18,19]$. Though the in vivo concentrations of these aldehydes are lower than those employed here, these in vivo numbers presumably reflect the low (steady-state) concentrations of these reactive carbonyls that have not undergone rapid reaction with plasma proteins; the true flux (rate of generation and removal) of these aldehydes has yet to be established.

Acknowledgements The authors are grateful to the Diabetes Australia Research Trust and the Australian Research Council for financial support. Ms B.E. Brown gratefully acknowledges receipt of an Australian Postgraduate Award administered through the University of Sydney. The authors thank Mr Pat Pisansarakit for the isolation of HUVECs, Dr Heather Knott for assistance in the LDL characterization work, and Dr David van Reyk and A. Prof. Wendy Jessup for helpful discussions.

\section{References}

1. Brownlee M (2001) Biochemistry and molecular cell biology of diabetic complications. Nature 414:813-820

2. Eaton JW, Dean RT (2000) Diabetes and atherosclerosis. In: Dean RT, Kelly DT (eds) Atherosclerosis. Oxford University Press, Oxford, pp 24-45

3. Ross R, Glomset MD (1976) The pathogenesis of atherosclerosis. N Engl J Med 295:369-377

4. Steinberg D (1997) Oxidative modification of LDL and atherogenesis. Circulation 95:1062-1071

5. Li AC, Glass CK (2002) The macrophage foam cell as a target for therapeutic intervention. Nat Med 8:1235-1242

6. Goldstein JL, Ho YK, Basu SK, Brown MS (1979) Binding site on macrophages that mediates uptake and degradation of acetylated low density lipoprotein, producing massive cholesterol deposition. Proc Natl Acad Sci U S A 76:333-337

7. Lopes-Virella MF, Klein RL, Virella G (1996) Modification of lipoproteins in diabetes. Diabetes Metab Rev 12:69-90

8. Tomkin GH, Owens D (2001) Abnormalities in Apo Bcontaining lipoproteins in diabetes and atherosclerosis. Diabetes Metab Res Rev 17:27-43

9. Lyons TJ, Jenkins AJ (1997) Lipoprotein glycation and its metabolic consequences. Curr Opin Lipidol 8:174-180

10. Baynes JW, Thorpe SR (2000) Glycoxidation and lipoxidation in atherogenesis. Free Radic Biol Med 28:1708-1716

11. Kawamura M, Heinecke JW, Chait A (1994) Pathophysiological concentrations of glucose promote oxidative modification of low density lipoprotein by a superoxide-dependent pathway. J Clin Invest 94:771-778

12. Baynes JW, Thorpe SR (1999) Role of oxidative stress in diabetic complications: a new perspective on an old paradigm. Diabetes 48:1-9

13. Chisolm GM, Steinberg D (2000) The oxidative modification hypothesis of atherogenesis: an overview. Free Radic Biol Med 28:1815-1826

14. Nagai R, Hayashi CM, Xia L, Takeya M, Horiuchi S (2002) Identification in human atherosclerotic lesions of GA-pyridine, a novel structure derived from glycolaldehyde-modified proteins. J Biol Chem 277:48905-48912

15. Schleicher ED, Wagner E, Nerlich AG (1997) Increased accumulation of the glycoxidation product $\mathrm{N}^{\varepsilon}$-(carboxymethyl)lysine in human tissues in diabetes and aging. J Clin Invest 99: $457-468$

16. Sakata N, Imanaga Y, Meng J et al (1999) Increased advanced glycation end products in atherosclerotic lesions of patients with end-stage renal disease. Atherosclerosis 142:67-77
17. Thornalley PJ, Langborg A, Minhas HS (1999) Formation of glyoxal, methylglyoxal and 3-deoxyglucosone in the glycation of proteins by glucose. Biochem J 344:109-116

18. Odani H, Shinzato T, Matsumoto Y, Usami J, Maeda K (1999) Increase in three $\alpha$, $\beta$-dicarbonyl compound levels in human uremic plasma: specific in vivo determination of intermediates in advanced Maillard reaction. Biochem Biophys Res Commun 256:89-93

19. Atkins TW, Thornally PJ (1989) Erythrocyte glyoxalase activity in genetically obese (ob/ob) and streptozotocin diabetic mice. Diabetes Res 11:125-129

20. Glomb MA, Monnier VM (1995) Mechanism of protein modification by glyoxal and glycolaldehyde, reactive intermediates of the Maillard reaction. J Biol Chem 270:1001710026

21. Reddy S, Bichler J, Wells-Knecht KJ, Thorpe SR, Baynes JW (1995) $\mathrm{N}^{\varepsilon}$-(carboxymethyl)lysine is a dominant advanced glycation end product (AGE) antigen in tissue proteins. Biochemistry 34:10872-10878

22. Lopes-Virella MF, Klein RL, Lyons TJ, Stevenson HC, Witztum JL (1988) Glycosylation of low-density lipoprotein enhances cholesteryl ester synthesis in human monocyte-derived macrophages. Diabetes 37:550-557

23. Knott HM, Brown BE, Davies MJ, Dean RT (2003) Glycation and glycoxidation of low-density lipoproteins by glucose and low-molecular mass aldehydes: formation of modified and oxidized particles. Eur J Biochem 270:3572-3582

24. Jessup W, Simpson JA, Dean RT (1993) Does superoxide have a role in macrophage-mediated oxidative modification of LDL? Atherosclerosis 99:107-120

25. Havel RJ, Hader HA, Bragdon JH (1955) The distribution and chemical composition of ultracentrifugally separated lipoproteins in human serum. J Clin Invest 34:1345-1353

26. Knight BL, Soutar AK (1982) Degradation by cultured fibroblasts and macrophages of unmodified and 1,2-cyclohexanedione-modified low density lipoprotein from normal and homozygous familial hypercholesterolaemic subjects. Biochem J 202:145-152

27. Basu SK, Goldstein JL, Anderson RGW, Brown MS (1976) Degradation of cationized low density lipoprotein and regulation of cholesterol metabolism in homozygous familial hypercholesterolemia fibroblasts. Proc Natl Acad Sci U S A 73: 3178-3182

28. Kritharides L, Jessup W, Mander E, Dean RT (1995) Apolipoprotein A-1-mediated efflux of sterols from oxidised LDL-loaded macrophages. Arterioscler Thromb Vasc Biol 15:276-289

29. Jessup W, Mander EL, Dean RT (1992) The intracellular storage and turnover of apolipoprotein B of oxidised LDL in macrophages. Biochim Biophys Acta 1126:167-177

30. Laemmli UK (1970) Cleavage of structural proteins during the assembly of the head of bacteriophage T4. Nature 227:680-685

31. Jaffe EA, Nachman RL, Becker CG, Minick CR (1973) Culture of human endothelial cells derived from umbilical veins: identification by morphologic and immunologic criteria. J Clin Invest 52:2745-2756

32. Dean RT, Hylton W, Allison AC (1979) Induction of macrophage lysosomal enzyme secretion by agents acting at the plasma membrane. Exp Cell Biol 47:454-462

33. Kritharides L, Jessup W, Gifford J, Dean RT (1993) A method for defining the stages of low-density lipoprotein oxidation by the separation of cholesterol- and cholesteryl ester-oxidation products using HPLC. Anal Biochem 213:79-89

34. Brownlee M (1995) Advanced protein glycosylation in diabetes and aging. Annu Rev Med 46:223-234

35. Sakata N, Uesugi N, Takebayashi S et al (2001) Glycoxidation and lipid peroxidation of low-density lipoprotein can synergistically enhance atherogenesis. Cardiovasc Res 49:466-475

36. Haberland ME, Olch CL, Fogelman AM (1984) Role of lysines in mediating interaction of modified low density lipoproteins with the scavenger receptor of human monocyte macrophages. J Biol Chem 259:11305-11311 
37. Haberland ME, Fogelman AM, Edwards PA (1982) Specificity of receptor-mediated recognition of malondialdehyde-modified low density lipoproteins. Proc Natl Acad Sci U S A 79:17121716

38. Bucala R, Mitchell R, Arnold K, Innerarity T, Vlassara H, Cerami A (1995) Identification of the major site of apolipoprotein B modification by advanced glycosylation end products blocking uptake by the low density lipoprotein receptor. J Biol Chem 270:10828-10832

39. Wang X, Bucala R, Milne R (1998) Epitopes close to the apolipoprotein $\mathrm{B}$ low density lipoprotein receptor-binding site are modified by advanced glycation end products. Proc Natl Acad Sci U S A 95:7643-7647

40. Thornalley PJ (1996) Pharmacology of methylglyoxal: formation, modification of proteins and nucleic acids, and enzymatic detoxification - $\mathrm{a}$ role in pathogenesis and antiproliferative chemotherapy. Gen Pharmacol 27:565-573

41. Sakurai T, Kimura S, Nakano M, Kimura H (1991) Oxidative modification of glycated low density lipoprotein in the presence of iron. Biochem Biophys Res Commun 177:433-439

42. Kobayashi K, Watanabe J, Umeda F, Nawata H (1995) Glycation accelerates the oxidation of low density lipoprotein by copper ions. Endocr J 42:461-465

43. Schalkwijk CG, Vermeer MA, Stehouwer CD, te Koppele J, Princen HM, van Hinsbergh VW (1998) Effect of methylglyoxal on the physico-chemical and biological properties of low-density lipoprotein. Biochim Biophys Acta 1394:187-198

44. Lo TW, Westwood ME, McLellan AC, Selwood T, Thornalley PJ (1994) Binding and modification of proteins by methylglyoxal under physiological conditions: a kinetic and mechanistic study with $N$-alpha-acetylarginine, $N$-alpha-acetylcysteine, and $\mathrm{N}$-alpha-acetyllysine, and bovine serum albumin. J Biol Chem 269:32299-32305

45. Degenhardt TP, Thorpe SR, Baynes JW (1998) Chemical modification of proteins by methylglyoxal. Cell Mol Biol (Noisy-le-grand) 44:1139-1145
46. Nagai R, Matsumoto K, Ling X, Suzuki H, Araki T, Horiuchi S (2000) Glycolaldehyde, a reactive intermediate for advanced glycation end products, plays an important role in the generation of an active ligand for the macrophage scavenger receptor. Diabetes 49:1714-1723

47. Boscoboinik DO, Chatelain E, Bartoli G-M, Stauble B, Azzi A (1994) Inhibition of protein kinase $c$ activity and vascular smooth muscle cell growth by D- $\alpha$-tocopherol. Biochim Biophys Acta 1224:418-426

48. Tasinato A, Boscoboinik D, Bartoli G-M, Maroni P, Azzi A (1995) D- $\alpha$-Tocopherol inhibition of vascular smooth muscle cell proliferation occurs at physiological concentrations, correlates with protein kinase $\mathrm{c}$ inhibition, and is independent of its antioxidant properties. Proc Natl Acad Sci U S A 92:1219012194

49. Guyton JR, Klemp KF (1994) Development of the atherosclerotic core region: chemical and ultrastructural analysis of microdissected atherosclerotic lesions from human aorta. Arterioscler Thromb 14:1305-1314

50. Esterbauer H, Gebicki J, Puhl H, Jurgens G (1992) The role of lipid peroxidation and antioxidants in oxidative modification of LDL. Free Radic Biol Med 13:341-390

51. Tabas I (1999) Non-oxidative modifications of lipoproteins in atherogenesis. Annu Rev Nutr 19:123-139

52. Steinbrecher UP, Witztum JL (1984) Glucosylation of lowdensity lipoproteins to an extent comparable to that seen in diabetes slows their catabolism. Diabetes 33:130-134

53. Lyons TJ, Klein RL, Baynes JW, Stevenson HC, Lopes-Virella MF (1987) Stimulation of cholesteryl ester synthesis in human monocyte-derived macrophages by low-density lipoproteins from type 1 (insulin-dependent) diabetic patients: the influence of non-enzymatic glycosylation of low-density lipoproteins. Diabetologia 30:916-923 